\title{
ANALISIS HUBUNGAN ANTARA BUDAYA ORGANISASI DAN IMPLEMENTASI INNOVATION TYPES DAN DAMPANYA PADA KINERJA MANAJER
}

\author{
Muhammad Dahlan \\ Fakultas Ekonomi dan Bisnis, Universitas Padjadjaran \\ E-mail: dahlanm2004@yahoo.com
}

\begin{abstract}
ABSTRAK. Tujuan utama penelitian ini adalah untuk menganalisis hubungan atara budaya organisasi dan kinerja manajer, serta implementasi inovasi sebagai variable perantara. Penelitian juga menguji peran BUMD berkontribusi positif dalam upaya peningkatan kepuasan pelayanan publik. Metode yang digunakan adalah time order decision. Analisis data menggunakan analisis regresi sederhana. Penyebaran kuesioner menggunakan jasa layanan pos dan menghasilkan 64 kuesioner siap olah. Berdasarkan hasil tes hipotesa menunjukan: budaya organisasi berhubungan positif terhadap kinerja,melalui implementasi inovasi, serta budaya organisasi dan inovasi berhubungan positif terhadap kinerja perusahaan.
\end{abstract}

Kata kunci: Budaya Organisasi; Implementasi Inovasi; Kinerja Pelayanan Publik; Kinerja Manajer; dan Badan Usaha Milik Daerah.

\section{ANALYSIS OF CORELATION BEETWEEN ORGANIZATION CULTURE ON IMPLEMENTATION OF INNOVATION TYPES AND ITS IMPACT ON MANAGER PERFORMANCE}

\begin{abstract}
To analyze the corelation among organization culture and implementation of innovation type and its impact to manager performance. That's also to measure the roles of BUMD as services providers to contributions on the increase of public service satisfaction. Data analyze were used regression analysist. Mail questionnaires were distributed than we have 64 questionnaires. Base on hypothesis testing show that: organizational culture has positive correlation with manager performance, implementation of innovation as a mediating variable; and organizational culture and implementation of innovation has positive correlation with manager performance.
\end{abstract}

Key words: Organizational Culture; Implementation of Innovation types; Public Service Performance; Manager Performace, and Distric-Owned Enterprise.

\section{PENDAHULUAN}

Wheelen dan Hunger (2015) menyarankan pelaku usaha untuk setiap entitas bisnis selayaknya menyusun berbagai strategi dan pedoman operasi yang biasanya minimal dirancang pada akhir tahun untuk dilaksanakan pada awal tahun berikutnya. Rancangan ini sebagai acuan dan target yang dapat dicapai yang merupakan ukuran kinerjanya. Dewasa ini hampir tidak ada pelaku bisnis yang tidak melaksanakan tugas penting ini. Strategi bisnis dan pengawasan yang baik sangatlah dibutuhkan untuk kesuksesan dimasa akan datang (Dahlan, et al, 2007). Hal ini menjadi momok bagi manajemen di akhir tahun ketika evaluasi kinerja dilakukan. Implementasi innovation types merupakan salah satu strategi dan upaya manajemen dalam rangka merebut pangsa pasar dan bersaing untuk meningkatkan kinerja perusahaan serta menciptakan budaya organisasi yang kondusif agar setiap organ organisasi dapat berjalan secara efektif dan efisien (Tidd dan Bessant, 2014).

Tradisi ini juga berlaku bagi perusahaan pemerintah, misalnya badan usaha milik pemerintah daerah (BUMD). Tidak hanya itu, sesuai Undang-Undang Dasar RI 1945 mengamanatkan semua kekayaan yang ada wajib dipergunakan yang sebesar-besarnya untuk kemakmuran rakyatnya. Hal ini dapat direalisasikan melalui peningkatkan peran budaya kerja dan implementasi inovasi agar perusahaan mampu mengelaborasi persaingan, peluang bisnis, perubahan lingkungan dan penciptaan inovasi layanan, produk dan jasa bagi memenangkan persaingan global sehingga kinerja meningkat (Daft (2007).
Namun, berbeda dengan hasil survey lapangan pada tahun 2018 yang menjelaskan tentang kinerja pelayanan publik badan usaha milik pemerintah daerah (BUMD) belum optimal capaiannya, sebagai contoh; penyediaan air bersih, pelayanan kesehatan harus antri yang panjang jika berobat, pasar tradisional belum tertata dengan baik, kebersihan lingkungan dan prasarana lahar parkir umum. Penulis sebagai warga Kota Bandung, dapat merasakan dimana kontribusi BUMD belum optimal kinerjanya, misalnya; penyediaan air bersih dan kebersihan tempattempat umum.

Berdasarkan uraian dan pandangan tersebut, penulis ingin melihat secara lebih dekat melalui melakukan penelitian untuk melihat secara dekat apakah memang demikian masih ada permasalahan terkait dengan peran, kinerja layanan, kinerja manajer, penyediaan sarana dan prasaran umum oleh BUMD Kota Bandung.

Perusahaan pada umumnya termasuk juga BUMD diharapkan mampu memenangkan persaingan dan merebut pasar serta peluang bisnis untuk dapat bertahan dan sukses dikemudian hari. Daft (2007) memberikan beberapa pandangan dan saran agar perusahaan eksis pada pencaturan bisnis global melalui disilplin kerja, etos kerja tinggi, berlaku adil, loyak kepada perusahaan, fokus pada bisnis yang dijalankan serta renponsif terhadap perubahan lingkungan. Kemudian Uzkurt, et al (2013) menjelaskan tidak hanya aspek budaya, tetapi informasi dan peran inovasi juga penting yang harus dikemas dan dibangun secara kontinyu agar kemampuan bersaing dan bertahan lebih kuat serta mamiliki kesiapan jangka panjang untuk 
menuju kemenangan dalam pencaturan bisnis global yang terus berubah yang sulit diprediksi kemana arahnya akan bergerak. Kemudian, Kalkan, et al (2014) jika manajemen perusahaan mendapatkan informasi yang akurat dan mendukung pengambilan keputusan maka aktivitas dari keputusan tersebut dapat membantunya terciptanya arah bisnis yang lebih baik dimasa akan datang.

Inovasi merupakan the 4Ps of innovation space yaitu paradigm (mental model), process, position, and product (services) jika diterapkan secara konsisten dan berkesinambungan dapat meningkatkan kinerja perusahaan dimasa akan datang (Tidd dan Bessant, 2014).

Inovasi terdiri dari kata 4P yaitu (1) product innovation merupakan perusahaan diharapkan selalu menghasilkan produk fisik dan non fisik untuk kebutuhan konsumen; (2) process innovation merupakan memiliki cara-cara baru dalam menjual produk-produk yang dihasilkan; (3) Position innovation merupakan perusahaan mampu memperkenalkan produk-produk baru dalam berbagai situasi yang dihadapinya, dan (4) Paradigm innovation merupakan semua organ organisasi memiliki mental positif dan etos kerja yang sejalan goal congruence perusahaan. Selanjutnya, inovasi tentunya menekankan kepada bagaimana manajer dan bawahan secara kontinyu dan konsisten menghasilkan kreativitas dan sinergi serta mampu membangun motivasi dan disiplin kerja. Sinerginitas ini menghasilkan kemampuan bersaing dan merebut pangsa pasar sehingga mendapatkan profit bagi perusahaan.

Selanjutnya, budaya organisasi adalah implementasi konsep adat istiadat dan kebiasaan manusia di daerah tertentu, seperti kebiasaan hidup, pola hidup, kebiasaan dalam berpakaian, kedisilinan, loyal kepada perusahaan, berlaku adil sesama dan lain segabaginya (Daft, 2007). Apabila dilaksanakan secara baik dan kontinyu akan memberikan menfaat positif bagi yang menjalankannya.

Apakah konsep budaya organisasi dan the $4 P S$ of innovation space dapat memberikan manfaat positif bagi perusahaan yang menjalankannya. Berikut adalah cuplikan tentang hasil penelitian terdahulu. Penelitian terdahulu menyatakan inovasi dan budaya organisasi berdampak positif terhadap kinerja perusahaan (Ahn, et al., 2015; Dahlan dan Sumaryana, 2017 dan Kalkan, et al., 2014). Bergitu juga Ting et al. (2012) dan Uzkurt, et al., (2013) pada perusahaan UMKM, inovasi dapat meningkatkan kinerja perusahaan. Namun hasil penelitian Uzkurt, et al., (2013) dan Zafar et al., (2016) menjelaskan inovasi dan budaya organisasi berpengaruh terhadap kinerja perusahaan UMKM jika peran manajemen tinggi dan iklim kerja kondusif. Sedangkan penelitian Ting, et al., (2012) menjelaskan bahwa implementasi inovasi dapat meningkatkan kinera, jika dimoderasikan oleh perubahan lingkungan eksternal. Selanjutnya, Zafar et al., (2016) menyatakan inovasi dapat juga bertindak sebagai perantara dalam hubungan antara budaya organisasi dan kinerja. Artinya budaya organisasi dan implementasi inovasi yang dilaksanakan secara baik dan konsisten diharapkan dapat mengubah kinerja perusahaan terus meningkat.

Mengacu kepada ulasan di atas, maka dapat digambarkan anak panah seperti berikut:

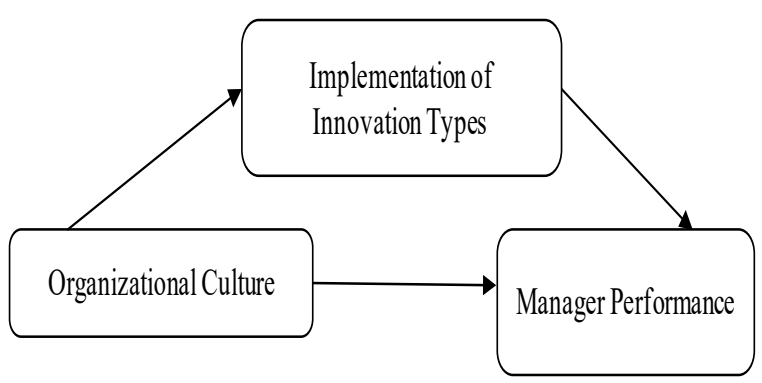

Gambar 1. Model Konseptual Penelitian.

Oleh karena itu, mengacu kepada research question, maka hipotesis yang diajukan sebagai berikut:

H1: Terdapat hubungan positif dan signifikan antara budaya organisasi dan imple mentasi inovasi dengan kinerja manajer.

\section{METODE}

Sampel penelitian ini adalah 7 perusahaan milik Pemerintah Kota Bandung (BUMD). Pengumpulan data mengacu kepada kuesioner 5-skala Likert (Sekaran dan Bougie) yang dirancang khusus dan disesuikan dengan BUMD. Menggunakan manajer perusahaan dan masyarakat pengguna jasa BUMD sebagai respoden, sehingga penelitian ini berhasil mengumpulkan kuesioner siap diolah adalah sebanyak 64. Disamping itu, penelitian ini juga menggunakan Time Order Decision dari Johnson dan Onwugbuzie's (2004) dalam Shauki (2016), metode ini untuk mewawancarai beberapa responden tertentu untuk menanyakan lebih lanjut atas data yang ada dan informasi-informasi lain yang releven dengan penelitian sebagai konfirmasi keabsahan data dan kondisi yang sesungguhnya memang demikian adanya.

Operasionalisasi variabel merupakan uraian indikator dan dimensi dari variabel penelitian yang dikaji dalam penelitian ini yaitu implementation of innovation types sebagaimana yang dijelaskan oleh Tidd dan Bessant (2014). Budaya organisasi yang berkaitan dengan layanan publik seperti kedisiplinan pegawai, ramah tamah, berlaku adil, loyal kepada perusahaan dan selalu menjungjung tinggi nilai-nilai positif (Daft, 2007). Sementara untuk kinerja perusahaan (K_Perusahaan) menggunakan dua aspek yaitu kinerja pelayanan publik dan kinerja kualitatif. Kinerja kualitatif diukur menggunakan indikator dan dimensi dari Mahoney, et al. (1963), sedangkan kinerja pelayanan publik menggunakan dan mengacu kepada UU Nomor 25 tahun 2009.

Pengujian data mengau kepada model regresi sederhana (Sekaran and Bougie, 2010) dan model persamaan regresi seperti berikut: 
$\mathrm{K}$ Pelayanan $($ Layanan Publik $)=\mathrm{C} 1+\mathrm{b} 1.1 \mathrm{INO}+$ $\mathrm{b} 1.2 \mathrm{BO}+\mathrm{e} 1$............. (1)

K_Manajer (Kualitatif) $\quad=\mathrm{C} 2+\mathrm{b} 2.1 \mathrm{INO}+\mathrm{b} 2.2 \mathrm{BO}$ $+\mathrm{e} 2$............. (1)

\section{HASIL DAN PEMBAHASAN}

\section{Statistik Deskriptif}

Berdasarkan pada tabel 1 di atas menjelaskan bahwa hasil tes data secara statistik deskriptif dapat disimpulkan data yang dianalisis dapat memberikan hasil yang akurat dan relevan sesuai uji yang dilakukan. Karena nilai minimum terendah 10,00, nilai maksimum terendah 17,45 , nilai mean tertinggi 40,97, standard deviasi terkecil 2,86, nilai KMO di atas 0,820 dan cormbach alpha di atas 0,870 .

\section{Analisis Korelasi}

Tabel 2: Korelasi Pearson

\begin{tabular}{|c|c|c|}
\hline Variabel & Correlations & BTS \\
\hline Total Performance & 1 & $446,982 * *$ \\
\hline $\begin{array}{l}\text { Implementation of Innovation } \\
\text { Types }\end{array}$ & $0,620 * *$ & $236,338 * *$ \\
\hline Organization Culture & 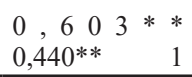 & $233,925 * *$ \\
\hline
\end{tabular}

**) Significant at the 0,01 (two-tailed)

Mengacu kepada tabel 2 di atas menunjukan bahwa tingkat korelasi antar veriabel penelitian ini berada pada posisi signifikan pada 0,01 dan hasil bartlet's test adalah di atas 233,920. Hasil ini semakin memperkuat bahwa hasil tes regresi akan memberikan hasil yang signifikan pula.

\section{Analisis Pengaruh}

Tabel 3: Pengaruh langsung dan tidak langsung

\begin{tabular}{lcccc}
\hline \multicolumn{4}{l}{ Dependent variable: Total Performance } & \\
& B & t-test & F-test & R-Square \\
$\begin{array}{l}\text { Constant } \\
\begin{array}{l}\text { Implementation } \\
\text { of Innovation }\end{array}\end{array}$ & 7,960 & 0,059 & 0,000 & 0,519 \\
$\begin{array}{l}\text { Types } \\
\begin{array}{l}\text { Organizational } \\
\text { culture }\end{array}\end{array}$ & 0,824 & 0,000 & & \\
& 0,974 & 0,000 & &
\end{tabular}

Dependent variable: Implementation of Innovation Types

$\begin{array}{lcccc}\begin{array}{l}\text { Constant } \\ \text { Organizational } \\ \text { culture }\end{array} & 9,683 & 0,000 & 0,000 & 0,194 \\ & 0,559 & 0,000 & & \end{array}$

Dependent variable: Public Service Performance

$\begin{array}{lcccc}\begin{array}{l}\text { Constant } \\ \text { Implementation } \\ \text { of Innovation }\end{array} & 7,452 & 0,002 & 0,000 & 0,381 \\ \begin{array}{l}\text { Types } \\ \begin{array}{l}\text { Organizational } \\ \text { culture }\end{array}\end{array} & 0,387 & 0,000 & & \\ & 0,352 & 0,000 & \end{array}$

\begin{tabular}{lcccc}
$\begin{array}{l}\text { Dependent variable: Manager Performance } \\
\text { Constant }\end{array}$ & 0,508 & 0,830 & 0,000 & 0,530 \\
$\begin{array}{l}\text { Implementation } \\
\text { of Innovation }\end{array}$ & & & & \\
$\begin{array}{l}\text { Types } \\
\begin{array}{l}\text { Organizational } \\
\text { culture }\end{array}\end{array}$ & 0,437 & 0,000 & \\
\hline
\end{tabular}

Analisis hubungan dilakukan melalui tiga model persamaan regresi yaitu analisis pengaruh terhadap total kinerja perusahaan, kinerja pelayanan publik, dan kinerja manajer. Berdasarkan tabel 3 di atas dapat disimpulkan seperti berikut:

a. Hasil uji regresi sederhana menunjukan budaya organisasi berpengaruh positif terhadap implementasi inovasi badan usaha milik daerah Kota Bandung.

b. Hasil uji regresi sederhana menunjukan budaya organisasi berpengaruh positif terhadap kinerja manajer badan usaha milik daerah Kota Bandung melalui implementasi inovasi

c. Hasil uji regresi sederhana menunjukan implementasi inovasi dan budaya organisasi berpengaruh positif terhadap kinerja manajer perusahaan badan usaha milik daerah Kota Bandung.

Hasil uji regresi di atas dapat menjadi konsideran peneliti bahwa apa yang telah dilakukan oleh beberapa peneliti terdahulu adalah mendukung dan konsisten dengan hasil penelitian terdahulu.

Beberapa penelitian terdahulu menyatakan variabel inovasi serta budaya organisasi berpengaruh positif terhadap kinerja manajer perusahaan (Ahn, et al., 2015; dan Kalkan, et al., 2014). Bergitu juga Ting et al. (2012) dan Uzkurt, et al., (2013) pada perusahaan UMKM memang implementasi inovasi sangat diharapkan pada akhirnya dapat meningkatkan kinerja perusahaan. Namun penelitian Uzkurt, et al., (2013) dan Zafar et al., (2016) menjelaskan variabel inovasi dan budaya organisasi berpengaruh terhadap kinerja perusahaan UMKM jika peran manajemen tinggi dan iklim kerja kondusif.

Sedangkan penelitian Ting, et al., (2012) menjelaskan inovasi berdampak positif terhadap kinera, jika dimoderasikan oleh perubahan lingkungan eksternal. Selanjutnya, Zafar et al., (2016) menyatakan variabel inovasi dapat juga bertindak sebagai mediating antara budaya organisasi dengan kinerja. Kemudian dapat diartikan H-1 dapat diterima, karena hasil uji konsisten dengan hasil penelitian sebelumnya. Perbedaannya hanya lokasi penelitian dan sampel penelitian yang digunakan, sementara penelitian ini menggunakan BUMD Kota Bandung sebagai sampel dan lokasinya di Indonesia.

\section{Tabel 1. Hasil Tes Statistik Deskriptif}

\begin{tabular}{lccccccc}
\hline \multicolumn{1}{c}{ Variabel } & N & Min & Max & Mean & SD & KMO & CA \\
\hline Total Performance & 64 & 27,00 & 53,00 & 40,97 & 6,81 & 0,853 & 0,908 \\
Implementation of Innovation Types & 64 & 11,00 & 25,00 & 19,44 & 3,63 & 0,828 & 0,877 \\
Organizational Culture & 64 & 10,00 & 23,00 & 17,45 & 2,86 & 0,822 & 0,915 \\
\hline
\end{tabular}


Penelitian ini menganalisis hubungan antara budaya organisasi, inovasi dan kinerja. Hasil tes menunjukan terdapat hubungan positif antara budaya organisasi, inovasi dan kinerja, baik kinerja manajer, kinerja perusahan dan kinerja pelayanan publik. Temuan ini konsisten dengan hasil penelitian sebelumnya.

Selanjutnya, hal ini bisa terjadi jika seluruh komponen yang harus selalu disiplin, berkharisma, berwibawa, transparan, menjungjung tinggi nilai-nilai positif, etos kerja, loyal kepada perusahaan serta berlaku adil untuk semua pihak yang dilayani. Disamping itu, dengan adanya nilai-nilai positif dan loyal kepada perusahaan maka pada saatnya nanti dan ditambah dengan dukungan manajemen dalam hal pendidikan berkelanjutan, program training dan workshop, sarana dan prasaran yang memadai, dapat diyakini bahwa inovasi demi inovasi dapat dihasilkan inovasi demi inovasi dapat diciptakan, misalnya; pola layanan, iklim kerja, produk baru, update perubahan global, serta kemajuan teknologi tepat guna akan terus dijangkau oleh karyawan dan manajer perusahaan, akhirnya tercapainya output dan kinerja perusahaan sebagaimana yang ditargetkan.

Secara umum dapat dikatakan bahwa hasil penelitian dan upay-upaya yang dilakukan perusahaan telah sesuai dengan amanat UUD tahun 1945. Akan tetapi hasil wawancara dengan beberapa responden terpilih baik dari internal perusahaan (manajer) maupun dari eksternal perusahaan (masyarakat pengguna jasa layanan perusahaan) menyatakan bahwa kinerja dan pelayanan publik yang memuaskan semua pihak belum optimal sebagaimana mestinnya, masih ada sektor-sektor tertentu pelayanan publik belum kunjung datang juga, misalnya; penyediaan air bersih, aspek keamanan, kebersihan pasar dan jalan kota serta desa, pelayanan kesehatan harus mengantri jika berobat, pasilitas parkir umum dan halte bis, pasar tradisional kurang tertata, dan drainase serta saluran tersier jika musim hujan tiba dapat mengalami banjir kecil dadakan. Hal ini bisa saja terjadi karena kemampuan BUMD yang terbatas dibandingkan dengan kebutuhan layanan yang harus tersedia.

Pengumpulan data menggunakan kuesioner, maka ini sebagai bentuk bias dalam pengumpulan data penelitian, sebab bisa ini tidak bisa dikontrol oleh peneliti. Hasil penelitian mendukung hasil penelitian terdahulu dan merekonfirmasi pentingnya the 4Ps of innovation space yaitu paradigm (mental model), process, position, and product (services), jika diterapkan secara konsisten dan berkesinambungan dapat meningkatkan kinerja perusahaan dimasa akan datang (Tidd dan Bessant, 2014).

\section{SIMPULAN}

Hasil penelitian menyatakan bahwa terdapat hubungan positif antara budaya organisasi dan implementasi innovation types dan dampaknya pada kinerja pelayanan publik dan kinerja manajer perusahaan BUMD Kota Bandung.
Kemudian budaya organisasi juga berpengaruh secara tidak langsung pada taraf positif dan signifikan terhadap kinerja pelayanan publik dan kinerja manajer perusahaan BUMD Kota Bandung dan implementasi innovation types sebagai pemediasi. Hal ini disebabkan oleh kedisiplinan, etos kerja, loyal, berlaku adil sesama, menjungjung tinggi nilai-nilai positif dan sebagainya. Kemudian para karyawan dan manajer selalu menciptakan pola-pola layanan terbaru, nilai-nilai positif bagi pengguna, secara berkala menghasilkan produk-produk baru dan pangsa pasar baru sehingga kinerja perushaan terus meningkat. Namun demikian, inovasi yang dilakukan belum berdampak secara luas hingga kelingkungan masyarakat misalnya penyediaan air bersih yang mengalir sampai jauh.

Penelitian ini mendukung hasil penelitian sebelumnya, budaya organisasi dan implementasi inovasi berpengaruh positif terhadap kinerja. Penelitian ini berbeda dengan penelitian terdahulu, dalan kajiannya implementasi innovation types sebagai variabel perantara dan the $4 P S$ of innovation space sebagai indikator dalam mengukur innovation types.

Pola kerja dan etos kerja serta inovasi secara kontinyu tidaklah cukup di zaman globalisasi ini, untuk itu, kami mengajak semua elemen baik karyawan dan manajer BUMD serta masyarakat haruslah selalu adanya koordinasi, harmonisasi, komunikasi dan manajer secara kontinyu melaksanakan sidak apa yang sesungguhnya sedang terjadi dilapangan, serta masyarakat tidak boleh bosan mengirimkan surat komplain dan pemberitahuan tentang apa-apa yang sedang terjadi di lapangan. Tujuannya adalah agar BUMD dapat menyediakan semua sarana dan prasarana bagi masyarakat pengguna dengan sebaikbaiknya dan seadil-adilnya.

\section{DAFTAR PUSTAKA}

Ahn, J.M., Minshall, T. \& Mortara, L. (2015), The relationaship between innovation and firm performance: an empirical evidence from Turkish automotive supplier industry. Procedia-social and behavioral sciences 75: 226-235.

Daft, R.L. (2007). Management. $6^{\text {th }}$ Edition. Singapore: Thomson Learning.

Dahlan, M., Auzair, S. Md., \& Ibrahim, W. Mzd. (2007). Tight Budgetary Control, Business Strategy, External Environment and Firm Performance. Malaysian Accounting Review. 6, (2), 81-97.

Dahlan, M. \& Sumaryana, A. (2017). Pengaruh penerapan good governance terhadap kinerja pelayanan publik, budaya organisasi dan lingkungan eksternal sebagai pemoderasi. Sosiohumaniora. 19, (1), 45-51.

Kalkan, A., Bozkurt, O.C. \& Arman, M. (2014), The impact of intellectual capital, innovation and 
organizational strategy on firm performance. Procedia-social and behavioral sciences 150: 700707.

Mahoney, T.A., Jerdee, T.H. \& Carrol, S.J. (1963). Development of Managerial Performance: a Research Approach. Cincinnati: South western Publishing.

Sekaran, U. \& Bougie, R. (2010). Research Methods for Business: A Skill Building Approach. Fifth edition. West Sussex: John Wiley \& Sons, Ltd.

Shauki, E.R. (2016). Enhancing the outcome data analysis by using mixed-method research. Handout Applied Research Method Part 2. Universitas Padjadjaran, Bandung.

Tidd, J. \& Bessant, J. (2014). Managing Innovation: Integrating Technology, marketandOrganizational Change. Fifth Edition. Italy: Printer Trento Srl.

Ting, H.F., Wang, B.W. \& Wang, D.S. (2012), The moderating role of environmental dynamism on the influence of innovation strategy and firm performance. International Journal of innovation, management and technology. 3, (5), 517-520.
Undang-Undang Dasar Republik Indonesia Tahun 1945. Dasar Negara. Jakarta.

Undang-Undang RI. No. 25 Tahun 2009. Pelayanan Publik. Jakarta.

Uzkurt, C., Kumar, R., Kimzan, H.S., \& Eminoglu, G. (2013), Role of innovation in the relationship between organizational culture and firm performance: a study on the banking sector in Turkey. Europen Journal of innovation Management. 16 (1): 92-117.

Wheelen, T.L. \& Hunger, J.D. (2015). Strategic Management and Business Policy: Achieving sustainability. Thirdteenth edition. Boston: Prentice Hall.

Zafar, H., Hafeez, M.H. \& Shariff, M.N.M. (2016), Relationship between market orientation, organizational learning, organizational culture and organizational: mediating impact of innovation. South East Asia Journal of Contemporary Business, Economics and Law. 9, (2), 40-56. 